\title{
An Updated Review of Abnormal Hemoglobins in the Turkish Population
}

\section{Anormal Hemoglobinlerin Türk Popülasyonunda Güncellenmesi}

\author{
Nejat Akar \\ TOBB-ETU Hospital, Ankara, Turkey
}

To the Editor,

Two previous reviews by Altay and Akar concerning the "Abnormal Hemoglobins in Turkey" appeared in the journal several years ago $[1,2]$. Since then, several other variants have been reported in both international and national journals. The aim of this mini-review was to compile the newly published abnormal hemoglobins in the Turkish population since these two previous papers [1,2].

During the last five years, several variants, each belonging to one family, confirmed with DNA sequencing were reported (Table 1) $[3,4,5,6,7,8,9,10,11,12,13,14,15,16,17,18,19,20$, 21,22]. Two further new variants (Hb İzmir and Hb Edirne) was reported in Turkish population for the first time [18,21].

It is interesting that although almost six decades had passed since the first determination of a hemoglobin variant, there are still reports on hemoglobin variants mainly related to clinical and genetic counselling.

Altay and Akar pointed out that the exact number of subjects having abnormal hemoglobins in Turkish population is not known due to the absence of a national registry system for these conditions $[1,2]$. So a national registry system collecting clinical and molecular data is needed.

This aim can be achieved under the auspices of the Turkish Hematology Association.

\section{Conflict of Interest Statement}

The author of this paper have no conflicts of interest, including specific financial interests, relationships, and/ or affiliations relevant to the subject matter or materials included.

Key Words: Hemoglobin, Variant, Hemoglobinopathy

Anahtar Kelimeler: Hemoglobin, Varyant, Hemoglobinopati

Address for Correspondence: Nejat AKAR, M.D.,

TOBB-ETU Hospital, Ankara, Turkey

E-mail: nejatakar@hotmail.com

Received/Geliş tarihi : December 20, 2012

Accepted/Kabul tarihi : January 10, 2013
Table 1. Abnormal hemoglobin variants in the Turkish population published since 2007.

a. Variants of the alpha chain (single base changes)

Hb Adana alpha 2(59)(E8)Gly-->Asp

Hb Westeinde $[\alpha 125($ H8)Leu $\rightarrow$ Gln combined with $\alpha 2$

IVS-I (-5 nt) deletion

Hb Q-Iran [a 75 (EF4) Asp-His]

b. Variants of the beta chain (single base changes)

$\mathrm{Hb}$ South Florida [beta 1(NA1) Val>Met

Hb Yaizu [beta 79(EF3) Asp>Asn]

Hb Sarrebourg [ $\beta 131(H 9)$ Gln $\rightarrow$ Arg, CAG>CGG]

Hb Crete [Betal29(H7) Ala>Pro]

$\mathrm{Hb}$ Izmir $[\beta 86(\mathrm{~F} 2) \mathrm{Ala} \rightarrow \mathrm{Val}, \mathrm{GCC}>\mathrm{GTC}$

Hb E Saskatoon (B22 Glu-Lys)

Hb Ernz [ $\beta 123(\mathrm{H1}) \mathrm{Thr}>\mathrm{Asn}]$

Hb D Punjab [B121 Glu-Gln]

Hb Beograd [B121 Glu-Val]

Hb G-Coushatta [B22 (B4) Glu-Ala]

Hb M Saskatoon (ß63 (E7) His>Tyr(C-T))

c. Variants of the delta chain (single base changes)

Hb Noah Mehmet Oeztuerk delta143 (H21) His-->Tyr

$\mathrm{Hb}$ A2 Yialousa (D82 C-T Ala28Ser)

d. Abnormal hemoglobin variants that have been

Reported in compound heterozygote state with thalassemia or sickle cell

Hb Ernz [ $\beta 123(\mathrm{H1})$ Thr>Asn] 


\section{References}

1. Altay Ç. Abnormal hemoglobins in Turkey. Turk J Hematol 2002;19:63-74.

2. Akar E, Akar N. A review of abnormal hemoglobins in Turkey. Turk J Hematol 2007;24:143-145

3. Atalay A, Koyuncu H, Köseler A, Ozkan A, Atalay EO.Hb Beograd [beta121(GH4)Glu-->Val, GAA-->GTA] in the Turkish population. Hemoglobin 2007;31:491-493.

4. Atalay EO, Atalay A, Ustel E, Yildiz S, Oztürk O, Köseler A, Bahadir A.Genetic origin of Hb D-Los Angeles [betal21(GH4) Glu-->Gln, GAA-->CAA] according to the beta-globin gene cluster haplotypes. Hemoglobin 2007;31:387-391.

5. Bissé E, Schaeffer C, Hovasse A, Preisler-Adams S, Epting T, Baumstark M, Van Dorsselaer A, Horst J, Wieland H.Haemoglobin Noah Mehmet Oeztuerk (alpha(2) delta(2)143 (H21)His-->Tyr: A novel delta-chain variant in the 2,3-DPG binding site. J Chromatogr B Analyt Technol Biomed Life Sci 2008;871:55-59.

6. Koseler A, Bahadır A, Koyuncu H, Atalay A, Atalay AO. First observation of Hb D-Ouled Rabah [beta19(B1)Asn>Lys] in the Turkish population. Turk J Hematol 2008;25:51-53.

7. Atalay EO, Atalay A, Koyuncu H, Oztürk O, Köseler A, Ozkan A, Demirtepe S. Rare hemoglobin variant Hb Yaizu observed in Turkey. Med Princ Pract 2008;17:321-324.

8. Kaufmann JO, Phylipsen M, Neven C, Huisman W, van Delft P, Bakker-Verweij M, Arkesteijn SG, Harteveld CL, Giordano PC. Hb St. Truiden $[\rightarrow 68$ (E17)Asn $\rightarrow$ His] and Hb Westeinde $[\rightarrow 125$ (H8)Leu $\rightarrow$ Gln]: two new abnormalities of the $\alpha 2$ globin gene. Hemoglobin 2010;34:439-444.

9. Keser I, Yeşilipek A, Canatan D, Lülec G. Abnormal hemoglobins associated with the beta-globin gene in Antalya province, Turkey. Turk J M Sci 2010:40:127-131.

10. Köseler A, Koyuncu A, Öztürk O, Bahadır A, Demirtepe S, Atalay A. First observation of Hb Tunis [beta124(H2) Pro $>$ Ser] in Turkey. Turk J Hematol 2010;27:120-122.

11. Curuk MA, Cavusoglu AÇ, Arıcan H, Uzuncan N, Karaca B. Hb Sarrebourg [ $\beta 131(\mathrm{H} 9)$ Gln $\rightarrow$ Arg, CAG>CGG] in Turkey. Hemoglobin 2010;34:572-575.
12. Zur B, Hildesheim A, Ludwig M, Stoffel-Wagner BA. First report on $\mathrm{Hb}$ Q-Iran in association with alpha-thalassemia in a case of spinal ischemia. Clin Lab 2011;57:221-224.

13. Arslan C, Kahraman S, Özsan H, Akar N. First observation of hemoglobin Crete [Beta129(H7) Ala>Pro] in the Turkish population I. Turk J Hematol 2011;28:346-347.

14. Genç A, Çürük MA. Two rare hemoglobin variants in the Çukurova Region of Turkey: $\mathrm{Hb}$ E-Saskatoon and $\mathrm{Hb}$ G-Coushatta. Turk J Hematol 2011;28:323-326.

15. Akar N, Arslan Ç, Kürekçi E. First Observation of Hemoglobin M Saskatoon (B63 (E7) His>Tyr(C-T)) in the Iraqi Population Turk J Hematol 2012:36;287-288.

16. Köseler A, Atalay A, Atalay E Ö. HbA2-Yokoshima (delta 25(B7)Gly >Asp) and Hb A2-Yialousa (delta 27(B9)Ala>Ser) in Turkey. Turk J Hematol 2012:36;289-290.

17. Genc A, Tastemir Korkmaz D, Urhan Kucuk M, Rencuzogullari E, Atakur S, Bayram S, Onderci M, Koc T, Aslan S, Mutalip A, Faruk M, Sevgiler Y, Tuncdemir A. Prevalence of beta-thalassemia trait and abnormal hemoglobins in the province of Adlyaman, Turkey. Pediatr Hematol Oncol. $2012 ; 29: 620-3$.

18. Celebiler A, Aksoy D, Ocakcı S, Karaca B.A new hemoglobin Variant: Hb Izmir [beta $\rightarrow$ 86(F2)Ala $\rightarrow$ Val, GCC $>$ GTC; HBB:c.260C>T. Hemoglobin 2012;36:474-479.

19. Gunesacar R, Celik MM, Ozturk OH, Celik M, Tümer C, Celik T. Investigation of the clinical and hematological significance of the first observed hemoglobin Ernz variant $[\beta 123(\mathrm{Hl})$ Thr>Asn] in the Turkish population. Turk J Med Sci 2012;42(Suppl 2):1471-1475.

20. Aslanger AD, Akbulut A, Tokgöz G, Türkmen S, Yararbaş K. First Observation of Hb South Florida [beta 1(NAl) Val>Met] in Turkey Turk J Hematol 2013;37:223-224.

21. Tabakçıoğlu K, Demir M. Hb-Edirne: A NewठChain Variant: [853 (D4)Asp> His; HBD c. 160G>C]. Hemoglobin, 2013.

22. Durmaz AA, Akin H, Ekmekci AY, Onay H, Durmaz B, Cogulu O, Aydinok Y, Ozkinay F.A severe alpha thalassemia case compound heterozygous for Hb Adana in alphal gene and $20.5 \mathrm{~kb}$ double gene deletion. J Pediatr Hematol Oncol. 2009 ;31(8):592-4. 